This is an Accepted Manuscript of an article published by Brill in European Journal of Crime, Criminal Law and Criminal Justice, Volume 16, Number 3, 2008, pp. 265-282, available online at:

\title{
A Definition that Could not Work: the EU Framework Decision on the Fight against Organised Crime.
}

\section{Francesco Calderoni}

This article argues that the definition of organised crime by the European Union Framework Decision on the Fight against Organised Crime (henceforth FD) is uncertain and vague, and that this makes the FD a poor instrument with little added value for the approximation of criminal legislation against organised crime. This criticism of the FD is based on both legal and criminological arguments, since the FD appears to be flawed from both perspectives.

In order to support the article's main thesis, the first section provides brief background information on organised crime, harmonisation and approximation of criminal law in the EU. The second section then analyses the definition of 'criminal organisation' as provided by the FD and the model offences criminalizing participation in a criminal organisation. Subsequently, the third section summarises the FD's problems relative to its added value in the approximation of criminal legislation against organised crime and suggests some possible improvements. The last section concludes. 


\section{Organised crime, harmonisation and approximation of national}

\section{criminal legislations.}

The concept of organised crime is debated both in criminal law and criminology. This is because the phenomenon is in itself complex and overlaps with economic crime, terrorism and even the legal economy, but also because state action to combat organised crime has frequently been uncertain and mostly symbolic, using the concept as a "picklock for criminal law and justice reforms" in order to increase police powers. ${ }^{1}$ After 11 September 2001 the main focus of the international crime and security agenda shifted from organised crime to terrorism, but the approach remained the same. The links between organised crime and terrorism suddenly became apparent and measures against organised crime were turned against terrorism. ${ }^{2}$

These difficulties long mirrored the lack of international consensus on a legal definition of organised crime. In the last decade this shortcoming was remedied by the 1998 Joint Action making it a criminal offence to participate in a criminal organisation in the Member States of the European Union (henceforth the JA3) and the United Nations

1 Letizia Paoli and Cyrille Fijnaut, "General Introduction," in Organised Crime in Europe: Concepts, Patterns and Control Policies in the European Union and Beyond, ed. Cyrille Fijnaut and Letizia Paoli (Dordrecht: Springer, 2004), p.5; Petrus C. van Duyne, "The Creation of a Threat Image: Media, Policy Making and Organised Crime," in Threats and Phantoms of Organised Crime, Corruption and Terrorism, ed. Petrus van Duyne et al. (Nijmegen: Wolf Legal Publishers, 2004); Monica De Boer, "Law-Enforcement Cooperation and Transational Organized Crime in Europe," in Transnational Organized Crime and International Security: Business as Usual?, ed. Mats Berdal and Mónica Serrano (Boulder: Lynne Rienner Publishers, 2002), p. 115; James O. Finckenauer, "Problems of Definition: What Is Organized Crime?" Trends in Organized Crime 8, no. 3 (Spring 2005), p. 73; Elisabeth Symeonidou-Kastanidou, "Towards a New Definition of Organised Crime in the European Union," European Journal of Crime, Criminal Law and Criminal Justice 15, no. 1 (2007), p. 89-92.

2 Alexandra V. Orlova and James W. Moore, "'Umbrellas" or "Building Blocks?": Defining International Terrorism and Transnational Organized Crime in International Law," Houston Journal of International Law 27 (2005), p. 298303.

3 Joint actions were introduced by Article K. 3 of the Treaty on European Union (Maastricht version). The norm did not explain the function and effects of these legal instruments. In the absence of clear provisions, about twenty 
Convention against Transnational Organized Crime of 2000 (henceforth Palermo Convention ${ }^{4}$. Whilst the problem of the legislative loophole has been solved, however, the quest for a definition which balances effective repression with the safeguarding of civil rights and liberties still continues, as the analysis of the FD will show.

In the context of the EU, the concern with organised crime touches on another sensitive issue: the harmonisation of criminal law. As in the case of 'organised crime', 'harmonisation' is another complex and blurred concept. In the scientific literature it is variously treated as an objective, a method or a process. This imprecision has given rise to different approaches and opinions on the harmonisation of criminal law, with animated debate between harmonisation enthusiasts and sceptics. Indeed, Article 31 of the Treaty on European Union enables approximation of criminal law through the adoption of "minimum rules concerning the constituent elements of criminal acts and penalties in the field of organised crime, terrorism and illicit drug trafficking." The Treaty on European Union and the EU instruments adopted under the III pillar use the concept of approximation. Whilst apparently similar, harmonisation and approximation are two different processes. From a more considered perspective, "harmonisation is the process of (re)ordering the relationship between diverse elements in accordance with a prefixed standard so as to avoid or eliminate friction" 5 , while approximation "corresponds with the idea of making two different systems more similar by eliminating some of the differences between them" 6 . The Council has

joint actions were approved in very disparate sectors, ranging from drugs and organised crime to police and judicial cooperation. The relative ease of adoption (compared to conventions) and the lack of obligations on Member States made joint actions useful tools for political purposes without any actual obligation upon governments.

4 The Palermo Convention was adopted by the General Assembly on 15 November 2000 and was open for signature from 12 to 15 December 2000 in Palermo and then in New York until 12 December 2002. It entered into force on 29 September 2003. Altogether, 147 States and regional economic integration organizations signed the Convention. As of May 2008 it has 143 Parties.

5 Felicitas M. Tadic, "How Harmonious Can Harmonisation Be? A Theoretical Approach Towards Harmonisation of (Criminal) Law," in Harmonisation and Harmonising Measures in Criminal Law, ed. André H. Klip and Harmen G. van der Wilt (Amsterdam: Royal Netherlands Academy of Science, 2002), p. 16.

\footnotetext{
${ }^{6}$ Felicitas M. Tadic, loc.cit, p.9.
} 

Crime.

nevertheless adopted a large number of measures under the III pillar of the Treaty on European Union, whose topic and degree of harmonisation clearly exceeds the limits set by the Treaty for approximation. ${ }^{7}$ This marked trend towards harmonisation of criminal law in the EU has been driven to a great extent by the supposed threat posed by organised crime internally to a Union without internal borders.

The alleged threat of organised crime and the supposed need for extensive harmonisation of criminal legislation of EU Member States have created a kind of selffulfilling device for increased EU influence on national criminal legislation. ${ }^{8}$ On the one hand, this process is the natural and obvious consequence of the progressive establishment of a European legal area, which started for a mere economic purpose and has enlarged its scope over the years. Indeed, some form of harmonisation of key issues of criminal norms is necessary to smooth the implementation of the principle of mutual recognition. ${ }^{9}$ On the other hand, the current institutional framework of the III pillar suffers from a well-known democratic deficit. The accountability and transparency of its decision-making process are inadequate and do not comply with the generally accepted principles of criminal legislation. Rejection of the Treaty establishing a Constitution for Europe blocked several much needed reforms to the III pillar, such as the introduction of the European Parliament as co-legislator with the Council and a more incisive role for the European Court of Justice. ${ }^{10}$ The recently

7 Gert Vermeulen, "Where Do We Currently Stand with Harmonisation in Europe?" in Harmonisation and Harmonising Measures in Criminal Law, ed. André H. Klip and Harmen G. van der Wilt (Amsterdam: Royal Netherlands Academy of Science, 2002), p. 70; Anne Weyembergh, "Approximation of Criminal Laws, the Constitutional Treaty and The Hague Programme," Common Market Law Review 42 (2005), p. 1569.

8 Joachim Vogel, "Why is the Harmonisation of Penal Law Necessary? A Comment," in Harmonisation and Harmonising Measures in Criminal Law, ed. André H. Klip and Harmen G. van der Wilt (Amsterdam: Royal Netherlands Academy of Science, 2002), p. 54.

9 Petter Asp, "Mutual Recognition and the Development of Criminal Law Cooperation Within the EU," in Harmonization of Criminal Law in Europe, ed. Erling J. Husabø and Asbjørn Strandbakken, Supranational Criminal Law: Capita Selecta, vol. 3 (Antwerpen: Intersentia, 2005), p. 32; Steve Peers, "Mutual Recognition and Criminal Law in the European Union: Has the Council Got It Wrong?" Common Market Law Review 41 (2004), p. 34; Gert Vermeulen, loc. cit., p. 71-73.

${ }^{10}$ Anne Weyembergh, loc. cit., p. 1593. 

Crime.

signed Treaty of Lisbon again seeks to introduce these very important innovations into the III pillar. ${ }^{11}$ If the Treaty enters into force, the three-pillar structure will be abolished and the European Parliament will be recognized as co-legislator, filling the democratic gap in the sector. Further improvements are the enhanced participation by national Parliaments as provided for by several protocols to be annexed to the Treaty, accession by the EU to European Convention for the Protection of Human Rights and Fundamental Freedoms, and improved control by the Court of Justice of the European Union. ${ }^{12}$

Therefore, from the standpoint of the approximation of criminal legislation, EU action against organised crime - of which the FD is a crucial element - exhibits a variety of perspectives ranging from the merely scientific approach to participation by the present writer in the current debate on security and protection of fundamental rights and civil liberties.

\section{The Framework Decision on the Fight against Organised Crime.}

The FD follows the JA and the Palermo Convention and is thus the third international instrument of law providing a definition of organised crime. ${ }^{13}$

The main impetus for a new EU instrument was imparted by the events of 11 September 2001, when terrorism became the absolute priority on the international agenda

11 The Treaty of Lisbon amending the Treaty on European Union and the Treaty establishing the European Community, signed in Lisbon on 13 December 2007, OJ, C 306 of 17/12/2007.

12 See the Protocol on the role of national Parliaments in the European Union, the Protocol on the application of the principles of subsidiarity and proportionality, Article 6 paragraph 2 of the Treaty on European Union as amended by the Treaty of Lisbon and Articles 220-245 of the Treaty on the Functioning of the European Union, formerly Treaty Establishing the European Community as amended by the Treaty of Lisbon.

13 The FD was proposed by the Commission in its Communication of 9 of January 2005 (European Commission, Proposal for a Council Framework Decision on the Fight Against Organised Crime, COM(2005)6, (2005)). The Council approved the final text on 28 of April 2006 (Council of the European Union, Doc. 12279/06 of 28 September 2006) Its entry into force is conditioned by publication in the Official Journal. This will occur when the parliamentary reservations posed by Denmark, France, Ireland, Netherlands, Sweden and the United Kingdom are lifted. 

Crime.

and many anti-organised crime measures were adopted to combat it. The "War on Terror" in part took the place of organised crime as a 'picklock' for the introduction of harsh legislation and the restriction of civil liberties. ${ }^{14}$ Although it is clear that many antiorganised crime activities can prove very effective in the repression of terrorism as well, the overlap between the two phenomena may lead to significant misunderstandings and confusion in combatting them. A well-known example is the Financial Action Task Force's (FATF) attempt to include terrorist financing in its anti money laundering Recommendations. This approach was ineffectual because it applied the same instrument to different targets. Money laundering is the aftermath of illegal activities and its function is to disguise the origin of the funds. The main challenge for law enforcement is thus to trace funds back to their illegal source. Terrorist financing is generally performed through legal channels, and investigative agencies consequently focus on anticipating when these activities may be diverted to support terrorism. ${ }^{15}$ Whilst organised crime and terrorism share some common features, they also have major differences. A proper criminal policy to deal with them must be aware of both aspects in order to take advantage of possible synergies but also to avoid misleading confusions. An example of this approach is the Communication of 29 March 2004 by the European Commission, stating that "a link should be established between measures to combat organised crime and terrorism". 16 The concept of criminal organisation introduced by the JA also extends to encompass terrorist groups. Consequently:

"The Union legislation on criminal organisations must therefore be toughened and made consistent with Union legislation on the fight against terrorism: a Framework Decision to supersede Joint Action 1998/733/JHA will be a major step

14 Alexandra V. Orlova and James W. Moore, loc. cit., p. 298-303; Hans-Heiner Kühne, "Terrorism Rediscovered: The Issue of Politically Inspired Criminality," in Migration, Culture Conflict, Crime and Terrorism, ed. Joshua D. Freilich and Rob. T. Guerette (Aldershot: Ashgate, 2006), p. 16.

15 Alexandra V. Orlova and James W. Moore, loc. cit., p. 301.

16 European Commission, Communication from the Commission to the Council and the European Parliament on Measures to Be Taken to Combat Terrorism and Other Forms of Serious Crime, in Particular to Improve Exchanges of Information, $\operatorname{COM}(2004) 221$ (2004), p. 4. 
forward in the fight against the most serious forms of crime. This will also be the most effective way of tackling the overall terrorist phenomenon." 17

For the Commission, the main objective of the updating of the JA was to "actually harmonise the definition of offences and penalties". 18 The reformatting of the JA was necessary in order to update it to take account of three main factors. The first was the Amsterdam Treaty, which had brought some innovations to the structure of the III pillar and in particular had introduced framework decisions expressly designed for the approximation of criminal legislation, binding upon Members States as to the results, but leaving them free to choose the instruments with which to implement them. The second factor was the signature and entry into force of the Palermo Convention, the first international treaty containing a legal definition of organised crime. Although the EU had participated in the drafting of the text and had tried to make it compatible with the JA, a newer instrument would have ensured closer compliance with the Palermo Convention. The third factor was the Framework Decision 2002/475/JHA of 13 June 2002 on combating terrorism, which was deemed to be "a much fuller" instrument. ${ }^{19}$ The new instrument of the framework decision had enabled EU Member States to adopt a common definition of terrorism only a few months after the attacks of $9 / 11$, proving to be effective and rapid. This experience suggested that the same results could be achieved in the field of organised crime, where the JA was not binding upon Member States.

\footnotetext{
17 European Commission, $\operatorname{COM}(2004) 221$, cit., p.7.

18 European Commission, COM(2004)221, cit., p.6.

19 European Commission, COM(2004)221, cit., p.6.
} 

Crime.

\subsection{The new definition of criminal organisation.}

\subsubsection{The "negative" definition of structured association.}

Art. 1 of the FD sets out the definition of a criminal organisation. ${ }^{20}$ The text largely adheres to both the definitions provided by the JA and the Palermo Convention. ${ }^{21}$ It defines a criminal organisation as "a structured association, established over a period of time, of more than two persons acting in concert...". Echoing the formulation of the JA, the first descriptor of a criminal organization is the presence of an association with at least three members. The structured nature of the association is inherently linked with the notion itself of organised

20 Art. 1 of the FD: "Definitions.

For the purposes of this Framework Decision:

1) "criminal organisation" means a structured association, established over a period of time, of more than two persons acting in concert with a view to committing offences which are punishable by deprivation of liberty or a detention order of a maximum of at least four years or a more serious penalty, to obtain, directly or indirectly, a financial or other material benefit;

2) "structured association" means an association that is not randomly formed for the immediate commission of an offence, nor does it need to have formally defined roles for its members, continuity of its membership, or a developed structure."

${ }^{21}$ Article 1, paragraph 1 of the JA: "Within the meaning of this joint action, a criminal organisation shall mean a structured association, established over a period of time, of more than two persons, acting in concert with a view to committing offences which are punishable by deprivation of liberty or a detention order of a maximum of at least four years or a more serious penalty, whether such offences are an end in themselves or a means of obtaining material benefits and, where appropriate, of improperly influencing the operation of public authorities."

Article 2 of the Palermo Convention: "Use of terms.

For the purposes of this Convention:

(a) 'Organized criminal group' shall mean a structured group of three or more persons, existing for a period of time and acting in concert with the aim of committing one or more serious crimes or offences established in accordance with this Convention, in order to obtain, directly or indirectly, a financial or other material benefit;

(b) "Serious crime" shall mean conduct constituting an offence punishable by a maximum deprivation of liberty of at least four years or a more serious penalty;

(c) "Structured group" shall mean a group that is not randomly formed for the immediate commission of an offence and that does not need to have formally defined roles for its members, continuity of its membership or a developed structure; [...]" 

Crime.

crime. ${ }^{22}$ The term may admit to a rather narrow interpretation (a simple association is something more than a mere group, and a structured association should therefore imply some kind of organisation). Conversely, the definition provided by the FD is markedly different. The concept of "structured association" is clarified at Article 1, point 2) of the FD, which follows to the letter the Palermo Convention definition of "structured group". It is a negative definition which states what a structured association is not, rather than furnishing some positive definitional features. ${ }^{23}$ The text only provides two extremes of a structured association's possible range of variation. The lower extreme excludes random groups formed to commit a single crime (the text mentions "an offence": but what about the case of multiple crimes?), the higher extreme excludes complex structure, formal hierarchy and constant composition as mandatory requirements. The range described comprises a broad variety of different criminal organisations, encompassing groups that may differ significantly in their social threat and seriousness of criminal intent.

The requirements of being "established over a period of time" and concert among the organisation's members restrict the application of the notion. Even if these criteria are widely acknowledged among scholars and law enforcement agencies, they are very vaguely formulated, with no further specifications. ${ }^{24}$ The duration criterion in particular only excludes minor or irrelevant cases. 25

From a legal point of view, the vague definition of the notion of structured association may raise problems relating to the principle of legality and its corollaries of

22 Valsamis Mitsilegas, "Defining Organised Crime in the European Union: The Limits of European Criminal Law in an Area of "Freedom, Security and Justice"," European Law Review 26 (2001), p. 569.

23 Elisabeth Symeonidou-Kastanidou, loc. cit., p. 97.

24 Valsamis Mitsilegas, loc.cit., p.577.

25 This requirement makes the legal definition of the FD even more ambiguous than the definition used by the EU and the Council of Europe for their annual reports on organised crime. In the latest definition a mandatory requirement is "a prolonged or indefinite period of time" (Council of the European Union, Doc. 6204/2/97 Enfopol $35 \operatorname{Rev} 2$ of 21 April 1997) Even in such a non-binding document more effort was made to provide a better specification of the idea of the continuous nature of organised crime. 

Crime.

clarity and precision of criminal law. ${ }^{26}$ The definition, as it appears, is so vague as to deprive the notion of structured association of large part of its selective potential. ${ }^{27}$ In order to make it compatible with the principle of legality, Members States will have to complete and specify the definition. The results may differ substantially among Member States. This uncertain understanding of the notion is likely to jeopardise the effective approximation of national legislation. Indeed, the implementation of the EU definition at the national level may end up with very different national definitions and approaches, depriving the original intent of all meaning.

From a criminological point of view, the definition covers an extremely broad span of phenomena and does not address the distinctive features of organised crime. ${ }^{28}$ These characterise organised crime and should be highlighted in order to distinguish it from mere "crimes that are organised". Indeed, "there is a danger, generally, in the promiscuous use of the label organized crime with reference to perpetrators of 'crimes that are organized,' and also with criminal networks that lack what we regard as the essential defining elements of being criminal organizations". ${ }^{29}$ The most accurate studies in the field have identified these elements in:

- Continuity: the group must have a stable structure suited to the continuous and indefinite commission of crimes, independently of its membership; 30

- Violence: the group exploits its force to use or to threaten to use violence or intimidation. This may be addressed to other criminal groups, minor criminals, legal/illegal competitors and victims; 31

26 Valsamis Mitsilegas, loc.cit., p.570.

27 Valsamis Mitsilegas, loc.cit., p.577.

28 Joi Bay, "Definitions of Organized Crime in the European Union: A Criminological Perspective," in Organised Crime \& Crime Prevention - What Works? Rapport Fra NSfK:S 40. Forskerseminar. Espoo, Finland 1998 (København: Scandinavian Research Council for Criminology, 1998), p. 31.

29 James O. Finckenauer, loc. cit., p. 77-78.

30 James O. Finckenauer, loc. cit., p. 66; Joi Bay, loc. cit., p.25; Frank E. Hagan, "'Organized Crime" and "organized crime": Indeterminate Problems of Definition," Trends in Organized Crime 9, no. 4 (Summer 2006), p. 135. 
- $\quad$ Enterprise: the group's main goals are profit and power. These are usually pursued through the production and/or exchange of illegal goods and/or services in illegal markets;32

- Immunity: the group can corrupt or exert influence on other subjects (politicians, media, judicial authorities, administrators, enterprises) in order to shield its activities from any form of sanction. ${ }^{33}$

None of these elements is clearly spelled out in the FD's definition of criminal organisation. The EU's notion of organised crime is thus far removed from the results of scientific research in the field.

\subsubsection{The rigid selection of the predicate offences.}

The illegal nature of the organisation derives from its objective of committing multiple crimes ("... with a view to committing offences which are punishable by deprivation of liberty or a detention order of a maximum of at least four years or a more serious penalty"). The requirement of a plurality of criminal acts has been inherited from the JA, whilst the Palermo Convention includes groups committing "one or more serious crimes". This possibility of a criminal organisation whose plan involves only one offence, albeit serious, raises some concern when the organisational requirements are minimal as for the Palermo Convention. ${ }^{34}$

The criminal plan of the organisation must include offences punishable with at least four years of maximum imprisonment, a quantitative threshold for what the EU considers to be a serious crime. ${ }^{35}$ This legislative technique has been inherited from both the JA and the Palermo Convention. Its aim is to restrict the applicability of the concept of criminal

31 James O. Finckenauer, loc. cit., p. 66, Joi Bay, loc. cit., p.26, Klaus von Lampe et al., "Organised Crime Is....Findings from a Cross-National Review of Literature," in The Organisation of Crime for Profit: Conduct, Law and Measurement, ed. Petrus C. van Duyne et al. (Nijmegen: Wolf Legal Publishers, 2006), p.36.

32 Frank E. Hagan, loc. cit., p. 134; James O. Finckenauer, loc. cit., p. 66-67

33 James O. Finckenauer, loc. cit., p. 67, Joi Bay, loc. cit., p. 27; Frank E. Hagan, loc. cit., p. 135.

${ }^{34}$ Alexandra V. Orlova and James W. Moore, loc. cit., p. 282.

35 Valsamis Mitsilegas, loc.cit., p.570. 

Crime.

organisation to serious crimes. ${ }^{36}$ Paradoxically, it ends up by being a rigid approach to the selection of the predicate offences. This rigidity raises several problems. The levels of penalties vary significantly among EU Member States, and there is no EU framework for criminal sanctions. ${ }^{37}$ Indeed, as Militello states, "proportionality between criminal acts and respective penalties is not an absolute concept but only a relative one measuring the scale of reaction of a particular legal order". 38

This quantitative threshold once again jeopardises the objective of approximating national legislation against organised crimes. Firstly, different offences (if committed by at least three people) may fall within the notion of criminal organisation, according to the sanctioning regime and tradition of each Member State. ${ }^{39}$ This may result in very different applications of the concept of criminal organisation and thus create problems in the coordination of law enforcement activities among Member States (e.g.: two identical behaviours in the territory of two different countries may be treated very differently). 40 Secondly, since many activities of criminal organisations usually fall within the competence of several jurisdictions, the differential application of the discipline on criminal organisations may imply very different criminal treatments depending on which state prosecutes the offences (e.g.: one behaviour may receive different treatments according to which state establishes its jurisdiction to prosecute it). The final result may be far from improving the level of approximation among Member States.

36 European Commission, COM(2005)6, cit., p.4.

37 Alexandra V. Orlova and James W. Moore, loc. cit., p. 282; Steve Peers, loc. cit.; Gert Vermeulen, loc. cit., p. 75-76; Vincenzo Militello, "Participation in a Criminal Organisation as a Model of European Criminal Offence," in Towards a European Criminal Law Against Organised Crime: Proposals and Summaries of the Joint European Project to Counter Organised Crime, ed. Vincenzo Militello and Barbara Huber (Freiburg: Iuscrim, 2001), p. 26.

38 Vincenzo Militello, loc. cit., p. 25.

39 Vincenzo Militello, loc. cit., p. 25.

40 Stefano Manacorda, "La Risposte Pénale Contre la Criminalité Organisée dans le Droit de I'Union Européenne," in L'infraction d'Organisation Criminelle en Europe: (Allemagne - Espagne - France - Italie - Union Européenne), ed. Stefano Manacorda (Paris: Presses Universitaires de France, 2002), p. 282. 
Besides the legal issues caused by the use of this technique, it also reflects a controversial criminal policy approach to the notion of organised crime. Instead of focusing on the distinctive features of the phenomenon, in order to provide a more penetrating definition (see above $\S 2.1 .1$ ), it dilutes the salient aspects of organised crime and transforms the notion into a generic container serving ideological and mutual cooperation purposes. ${ }^{41}$ This intention is evident in the above-cited Commission Communication, where the FD is presented as a measure complementary to the Framework Decision on combating terrorism. ${ }^{42}$ This choice of criminal policy may have important drawbacks. The label "criminal organisation" has serious consequences in terms of police control and derogations to standard procedural guarantees. The level of state reaction requires that the crimes involved be proportionally serious. The FD definition however does not focus on the distinctive features of organised crime that may justify the substantial increase in the investigation, prosecution and sanctioning regime. The combination of the critical points described above prevents setting a sensible threshold for the application of the notion of criminal organisation, opening the way for possible excesses of repression. ${ }^{43}$

The FD definition does not depart substantially from the definitions provided in the previous international instruments. It remedies some minor problems with the JA by importing solutions from the Palermo Convention. ${ }^{44}$ This shows that the European legislator has disregarded the criticisms made of the excessive vagueness and meaninglessness of the

41 Joy Bay, loc.cit., p. 32.

42 European Commission, $\operatorname{COM}(2004) 221$, cit., p. 7.

43 Elisabeth Symeonidou-Kastanidou, loc. cit., p. 92 and 96.

44 In particular, the simple clause introduced by the Palermo Convention ("to obtain, directly or indirectly, a financial or other material benefit") substitutes for the somewhat problematic description of the ultimate objectives of the organisation in the JA ("[...] whether such offences are an end in themselves or a means of obtaining material benefits and, where appropriate, of improperly influencing the operation of public authorities."). Article 1 paragraph 2 of the JA providing a superfluous and unclear cross-reference to the offences contained in the Europol Convention has not be been maintained. 

Crime.

JA. 45 The Council has failed to address the core characteristics of organised crime. The definition of "structured association" is thus a nebulous oxymoron challenging legal certainty. 46 The quantitative selection of the predicate offences does not dispel this vagueness, because of the sanctioning disparities among national systems. This broad approach to the concept finally dilutes it in order to extend its application and apparently reduce discrepancies among EU MS. ${ }^{47}$

\subsection{Offences relating to participation in a criminal organisation.}

\subsubsection{The double model offence.}

The FD requires Member States to criminalize participation in a criminal organisation. Article 2 envisages a double model offence: 48 national legislators are allowed to choose

45 Joy Bay, loc.cit., p. 32; Vincenzo Militello, loc. cit.; Stefano Manacorda, loc. cit.;Anne Weyembergh, loc. cit.; Valsamis Mitsilegas, loc.cit.

46 Elisabeth Symeonidou-Kastanidou, loc. cit., p. 97-98; Valsamis Mitsilegas, loc.cit., p. 576-577.

47 Joy Bay, loc.cit., p. 32.

48 Article 2 of the FD: "Offences relating to participation in a criminal organisation

Each Member State shall take the necessary measures to ensure that one or both of the following types of conduct related to a criminal organisation are regarded as offences:

(a) conduct by any person who, with intent and with knowledge of either the aim and general activity of the criminal organisation or its intention to commit the offences in question, actively takes part in the organisation's criminal activities, including the provision of information or material means, the recruitment of new members and all forms of financing of its activities, knowing that such participation will contribute to the achievement of the organisation's criminal activities;

(b) conduct by any person consisting in an agreement with one or more persons that an activity should be pursued, which if carried out, would amount to the commission of offences referred to in Article 1 , even if that person does not take part in the actual execution of the activity." 

Crime.

either or both a civil law model offence and a common law model offence. ${ }^{49}$ This approach was introduced by the $\mathrm{JA}^{50}$ and maintained by the Palermo Convention. ${ }^{51}$

49 The archetypes of the two model offences can be traced to the French association de malfaiteurs and the English conspiracy offences respectively.

50 Article 2 of the JA: "1. To assist the fight against criminal organisations, each Member State shall undertake, in accordance with the procedure laid down in Article 6, to ensure that one or both of the types of conduct described below are punishable by effective, proportionate and dissuasive criminal penalties:

(a) conduct by any person who, with intent and with knowledge of either the aim and general criminal activity of the organisation or the intention of the organisation to commit the offences in question, actively takes part in:

- the organisation's criminal activities falling within Article 1, even where that person does not take part in the actual execution of the offences concerned and, subject to the general principles of the criminal law of the Member State concerned, even where the offences concerned are not actually committed,

- the organisation's other activities in the further knowledge that his participation will contribute to the achievement of the organisation's criminal activities falling within Article 1;

(b) conduct by any person consisting in an agreement with one or more persons that an activity should be pursued which, if carried out, would amount to the commission of offences falling within Article 1, even if that person does not take part in the actual execution of the activity."

51 Article 5 of the Palermo Convention: "Each State Party shall adopt such legislative and other measures as may be necessary to establish as criminal offences, when committed intentionally:

(a) Either or both of the following as criminal offences distinct from those involving the attempt or completion of the criminal activity:

(i) Agreeing with one or more other persons to commit a serious crime for a purpose relating directly or indirectly to the obtaining of a financial or other material benefit and, where required by domestic law, involving an act undertaken by one of the participants in furtherance of the agreement or involving an organized criminal group;

(ii) Conduct by a person who, with knowledge of either the aim and general criminal activity of an organized criminal group or its intention to commit the crimes in question, takes an active part in

a. Criminal activities of the organized criminal group;

b. Other activities of the organized criminal group in the knowledge that his or her participation will contribute to the achievement of the above described criminal aim;

(b) Organizing, directing, aiding, abetting, facilitating or counselling the commission of serious crime involving an organized criminal group. [...]" 
The civil law model offence comes from the European continental legal tradition. While both the JA and the Palermo Convention sought to distinguish between participation in the organisation's criminal activities and in its other activities, the solution adopted in FD is slightly different. The criminal conduct now encompasses active participation in the criminal activities of the organisation. A list of formally non-criminal support activities, comprising the provision of information or material means, the recruitment of new members and all forms of financing, is included in the notion of active participation. These behaviours describe the typical activities of the leaders of groups and other "external" contributors, and they are criminalized because of their essential role of supporting the activities of a criminal organisation.

Both criminal and support activities require that the participant must know that the organisation is either a criminal one or intends to commit offences, and that their participation will contribute to the organisation's criminal activities.

In regard to the civil law model offence, the FD does not substantially diverge from the discipline set by the JA and the Palermo Convention. It resolves some critical issues but the main approach is still the same: a very broad definition of criminal organisation (see above 2.1.1) and a quantitative selection of the predicate offences (see above §2.1.2) are combined with a very poor description of the material element of the model offence which nearly coincides with the mere participation in a crime. ${ }^{52}$ Indeed, an extremely broad array of crimes (committed by at least three people with a minimum level of co-ordination) may fall within the definition of Article 2 of the FD. ${ }^{53}$ Virtually any group, provided that it is engaged in an activity sanctioned with at least four years of imprisonment, could be prosecuted for the offence of "participation in a criminal organisation". This may also include activities that "were not aimed to be included in the first place" in the definition of organised crime. ${ }^{54}$ From

52 Stefano Manacorda, loc. cit., p. 283; Weyembergh, loc. cit., p. 1588-1589.

53 Letizia Paoli and Cyrille Fijnaut, "Introduction to Part I: The History of the Concept," in Organised Crime in Europe: Concepts, Patterns and Control Policies in the European Union and Beyond, ed. Cyrille Fijnaut and Letizia Paoli (Dordrecht: Springer, 2004), p.41; Elisabeth Symeonidou-Kastanidou, loc. cit., p. 93.

54 Valsamis Mitsilegas, loc.cit., p.570. 

Crime.

this perspective, the civil law model offence is likely to conflict with the principle of clarity and precision of criminal legislation. The FD does not establish a clear division between participation in a criminal organisation and mere participation in a crime which is conventionally recognized by all national criminal legislation according to the legal culture of each Member State. 55

The common law model offence recalls the crime of conspiracy in the Anglo-Saxon tradition. This provision of the FD follows to the letter the corresponding provision of the JA. Members States may punish mere agreement between two people in order to commit the crimes falling under Article 1 of the FD. This possibility has been included in the JA in order to obtain the consensus of the common law Member States, where criminal organisations are pursued through the offence of conspiracy. ${ }^{56}$ The criminal agreement must be "related to a criminal organisation". This element is a slight improvement on the JA, which did not require any explicit relation with a criminal organisation.

\subsubsection{A motionless approximation.}

The above-described double model offence approach is another problematic issue concerning the FD. First introduced by the JA and also maintained by the Palermo Convention, it represents a solution by political compromise between the continental tradition of associative offences and the Anglo-Saxon conspiracy tradition. During the JA negotiations, the common law model offence was introduced because of the reaction by the United Kingdom, as also happened in the case of the FD. 57 While the Commission's proposal had suggested a single model offence based on the continental tradition, this was not retained by the Council, which introduced a conspiracy clause. This happened because

"IE and UK thought that the alternative option of criminalising conspiracy from the 1998 Joint Action should be maintained. UK referred to the evidentiary difficulties UK prosecutorial authorities would be faced with when trying to prove membership of a criminal

\footnotetext{
55 Stefano Manacorda, loc. cit., p. 290.

56 Stefano Manacorda, loc. cit., p. 287.

57 Valsamis Mitsilegas, loc.cit., p.570.
} 
organisation. In view of these legitimate law enforcement concerns and at the suggestion of $\mathrm{BE}$, the Presidency proposes to reinsert the alternative referring to conspiracy." 58

It is clear that the present solution has been introduced into the text of the FD in order to obtain the consensus of the common law Member States, where criminal organisations are pursued through the device of conspiracy. ${ }^{59}$ This happened because Article $34 \S 2$ of the Treaty on European Union still requires unanimity for the adoption of framework decisions.

This compromise is once again problematic in light of the objective itself of framework decisions, i.e. the approximation of the criminal legislations of Member States.60 This outcome appears to be undermined by the final text approved by the Council. Indeed, the common law and civil law approaches are equalized as far as their function is concerned, without any substantial approximation of national disciplines. ${ }^{61}$ Most EU Member States will not have to change or modify their current legislation concerning the criminalization of participation in a criminal organisation. The FD fails to establish a common European criminal law approach to the repression of organised crime. This choice seems to jeopardize the added value of the FD in the perspective of improving law enforcement and judicial cooperation in criminal matters through the approximation of criminal law. ${ }^{62}$

This view is confirmed by the blunt statement by the Commission, joined by France and Italy, concerning the final text of the FD:63 The Commission affirms that "the Framework Decision does not achieve the minimum degree of approximation of acts of directing or participating in a criminal organisation on the basis of a single concept of such an organisation". Moreover, the FD "enables Member States not to introduce the concept of

\footnotetext{
58 Council of the European Union, Doc. 9864/05 of 8 June 2005 (2005), p.6, footnote 3.

59 Stefano Manacorda, loc. cit., p. 287; Valsamis Mitsilegas, loc.cit., p.571.

60 Stefano Manacorda, loc. cit., p. 287-288.

61 Stefano Manacorda, loc. cit., p. 287.

62 Stefano Manacorda, loc. cit., p. 270, Gert Vermeule, loc.cit., p.71-74; Anne Weyembergh, loc. cit., p. 1582.

63 Council of the European Union, Doc. 9067/06 of 10 May 2006 (2006), p.12.
} 
criminal organisation but to continue to apply existing national criminal law by having recourse to general rules on participation in and preparation of specific offences". Finally, it states that the FD "does not achieve the objective of the approximation of legislation on the fight against transnational organised crime as provided for in the Hague Programme". This declaration highlights the extent to which the issue is still debated and its complexity. Even if the Commission adopts some of the most typical organised crime rhetoric in its proposal, its statement on the final text makes the point.

\section{Problems with Framework Decisions and Possible improvements.}

The description of the definition of criminal organisation and the offences relating to the participation in a criminal organisation provided by the FD highlight some major problems.

\section{The $F D$ is vague:}

The definition of criminal organisation is based on the notion of structured association. However, the hermeneutic potential of this concept is erased because of its negative definition (see above $\S 2.1 .1$ ). The concept of criminal organisation is thus extended to encompass a very broad range of organizational patterns which are unlikely to warrant the same attention and repression. This broad definition does not satisfy the fundamental requisites of clarity and precision in criminal legislation.

The civil law model offence of participating in a criminal organisation does not significantly differ from mere participation in a crime (see above $\S 2.2 .1$ ). Again, this contrasts with key principles of criminal legislation.

A possible solution would be to have the definition of criminal organisation or the material element of the model offence comprise one or more distinctive features identified by scientific research on organised crime (see above under 2.1.1). As shown above, the FD's definition does not clearly require any element of continuity, violence/intimidation, enterprise or immunity. Their inclusion would restrict the application of the FD and improve 
its clarity and precision from both a criminological and legal perspective. This solution might increase the workload of law enforcement agencies and prosecutions, which will have to prove the presence of these features in court. However, this seems a price worth paying in order to restrict application of the offence to serious criminal groups, in accordance with the basic principles of criminal law.

\section{The FD is rigid.}

The quantitative threshold for the selection of predicate offences does not take account of the very different sanctioning regimes and traditions of EU MS. This may give rise to diverse conceptions of criminal organisations among national systems. One MS may consider a particular group to be a criminal organisation, whilst another may not because of the different penalties inflicted on the predicate offences. This would hamper clear identification of a core set of serious criminal activities typically carried out by organised criminals.

A possible solution would be the inclusion of a list of predicate offences. Even if this approach has been discarded by the Commission, ${ }^{64}$ it would clearly specify the typical activities of criminal organisations. These might correspond to those serious crimes subject to EU intervention, such as drug trafficking, corruption, smuggling of human beings and money laundering, and thus represent a "core of common disvalue" agreed by all Member States.65 In this regard, the Joint European Project to Counter Organised Crime has suggested "murder, kidnapping, drug trafficking, money laundering, human trafficking and corruption" as possible core offences. ${ }^{66}$ The objection that crime evolves much more rapidly than legislation, so that the list may rapidly become obsolete, can be rebutted with the argument that the list should not be rigid, but open to other serious criminal activities, possibly decided by a further decision by the Council and the Parliament.

\footnotetext{
64 European Commission, $\operatorname{COM}(2005) 6$, cit., p. 4.

65 Vincenzo Militello, loc. cit., p.29.

66 Vincenzo Militello, loc. cit., p.27.
} 


\section{The FD does not approximate MS legislation.}

The criminalization requirements of the FD maintain the double model offence approach. While this solution allows flexibility and the adoption of a model offence familiar to the different legal cultures of the Member States, it is right to wonder whether approximation is achievable while maintaining these two very different approaches. The present result is a political compromise caused by the need for unanimity within the Council rather than a choice of legislative technique.

A possible solution would be the adoption of a single model offence. This should be a flexible model which synthesises different traditions and remedies the current situation of two parallel definitions. ${ }^{67}$ This would certainly oblige some Members States to modify their national legislations significantly. However, it should be borne in mind that this seems to be the future trend of judicial cooperation on criminal matters, given that the European Constitution and the Treaty of Lisbon submit the adoption of instruments approximating criminal law to qualified majority voting, thus abandoning the unanimity principle. From the perspective of increasing convergence among criminal justice systems in the EU, it is unlikely that national particularities will be maintained for serious crimes whose repression requires a certain level of harmonisation in order to support international cooperation.

\section{Conclusions.}

The FD is the third international instrument defining organised crime and requiring the criminalization of participation in a criminal organisation. It draws on the previous instruments, making only some minor changes and improvements to them. This conservatism makes the FD vulnerable to the criticism brought against both the JA and the Palermo Convention, with the additional flaw of not learning from previous mistakes. Analysis of the measure has highlighted several critical deficiencies and showed that its

\footnotetext{
67 Stefano Manacorda, loc. cit., p. 287.
} 

Crime.

possible value added for the approximation of Member States's legislations appears to be low. It does not push towards a common model offence of participation in a criminal organisation, allowing each country to keep its current discipline without any substantial change. Most of its content would probably have been implemented through ratification of the Palermo Convention. ${ }^{68}$ Driven by the need for compromise and the will not to depart from the Palermo Convention, the Council has probably missed an important opportunity to provide the EU with a sensible and meaningful common definition of organised crime.

68 As of May 2008, the Palermo Convention has been ratified by all Member States except the Czech Republic, Greece, Ireland and Luxembourg (see http://www.unodc.org/unodc/en/treaties/CTOC/countrylist.html). 